\title{
Front Matter: Volume 9177
}

, "Front Matter: Volume 9177," Proc. SPIE 9177, Thin Films for Solar and Energy Technology VI, 917701 (11 November 2014); doi: 10.1117/12.2084870

SPIE Event: SPIE Solar Energy + Technology, 2014, San Diego, California, United SPIE. States 


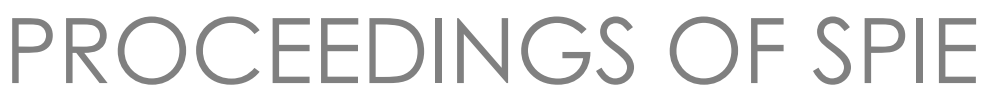

\section{Thin Films for Solar \\ and Energy Technology VI}

Louay A. Eldada

Michael J. Heben

Editors

17, 18 and 20 August 2014

San Diego, California, United States

Sponsored and Published by

SPIE 
The papers included in this volume were part of the technical conference cited on the cover and title page. Papers were selected and subject to review by the editors and conference program committee. Some conference presentations may not be available for publication. The papers published in these proceedings reflect the work and thoughts of the authors and are published herein as submitted. The publisher is not responsible for the validity of the information or for any outcomes resulting from reliance thereon.

Please use the following format to cite material from this book:

Author(s), "Title of Paper," in Thin Films for Solar and Energy Technology VI, edited by

Louay A. Eldada, Michael J. Heben, Proceedings of SPIE Vol. 9177 (SPIE, Bellingham, WA, 2014)

Article CID Number.

ISSN: 0277-786X

ISBN: 9781628412048

Published by

SPIE

P.O. Box 10, Bellingham, Washington 98227-0010 USA

Telephone +1 3606763290 (Pacific Time) · Fax +1 3606471445

SPIE.org

Copyright (C) 2014, Society of Photo-Optical Instrumentation Engineers.

Copying of material in this book for internal or personal use, or for the internal or personal use of specific clients, beyond the fair use provisions granted by the U.S. Copyright Law is authorized by SPIE subject to payment of copying fees. The Transactional Reporting Service base fee for this volume is $\$ 18.00$ per article (or portion thereof), which should be paid directly to the Copyright Clearance Center (CCC), 222 Rosewood Drive, Danvers, MA 01923. Payment may also be made electronically through CCC Online at copyright.com. Other copying for republication, resale, advertising or promotion, or any form of systematic or multiple reproduction of any material in this book is prohibited except with permission in writing from the publisher. The CCC fee code is 0277-786X/14/\$18.00.

Printed in the United States of America.

Publication of record for individual papers is online in the SPIE Digital Library.

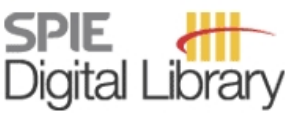

SPIEDigitalLibrary.org

Paper Numbering: Proceedings of SPIE follow an e-First publication model, with papers published first online and then in print and on CD-ROM. Papers are published as they are submitted and meet publication criteria. A unique, consistent, permanent citation identifier (CID) number is assigned to each article at the time of the first publication. Utilization of CIDs allows articles to be fully citable as soon as they are published online, and connects the same identifier to all online, print, and electronic versions of the publication. SPIE uses a six-digit CID article numbering system in which:

- The first four digits correspond to the SPIE volume number.

- The last two digits indicate publication order within the volume using a Base 36 numbering

system employing both numerals and letters. These two-number sets start with 00, 01, 02, 03, 04, $05,06,07,08,09,0 A, 0 B \ldots$. 0Z, followed by 10-1Z, 20-2Z, etc.

The CID Number appears on each page of the manuscript. The complete citation is used on the first page, and an abbreviated version on subsequent pages. Numbers in the index correspond to the last two digits of the six-digit CID Number. 


\title{
Contents
}

\author{
$\checkmark \quad$ Authors \\ vii Conference Committee \\ ix Hot carrier solar cell absorbers: materials, mechanisms and nanostructures \\ (Solar Energy Plenary Paper) [9178-304] \\ xxi International PV QA Task Force's proposed comparative rating system for PV modules \\ (Solar Energy Plenary Paper) [9178-305]
}

SOLAR ENERGY PLENARY SESSION

917702 The renaissance of CdTe-based photovoltaics (Solar Energy Plenary Paper) [9177-302]

SESSION 1 TESTING AND CHARACTERIZATION

917703 IR-imaging and non-destructive loss analysis on thin film solar modules and cells [9177-1]

917704 Test and analysis of thin film photovoltaic (TFPV) for UAV application [9177-2]

917705 Synchronized thermography for multi-layer thin film characterization [9177-3]

\section{SESSION 2 THIN-FILM ABSORBERS}

917708 Effects of sputtering technique on quaternary sputtered $\mathrm{Cu}(\mathrm{In}, \mathrm{Ga}) \mathrm{Se}_{2}$ films [9177-6]

\section{SESSION $3 \quad$ PEROVSKITES AND ADVANCED CONCEPTS}

9177 OC Systematic study of metal-insulator-metal diodes with a native oxide [9177-12]

9177 OE Microcrystalline silicon oxides for silicon-based solar cells: impact of the O/Si ratio on the electronic structure [9177-14]

\section{SESSION 4 HYDROGEN GENERATION AND CONTACTS}

9177 OF Strain dependence of the optical properties and band gap of transparent conducting $\mathrm{BaSnO}_{3}$ and $\mathrm{SrSnO}_{3}$ [9177-15]

9177 OG Development of transparent and conductive Al doped $\mathrm{Zn}_{1-\mathrm{x}} \mathrm{Mg}_{\mathrm{x}} \mathrm{O}$ thin film by sol-gel process with two-step annealing [9177-16] 
91770 Metal nanowire-graphene composite transparent electrodes [9177-18]

$91770 \mathrm{~J} \quad$ Transparent conducting electrodes based on thin, ultra-long copper nanowires and graphene nano-composites [9177-19]

\section{SESSION $5 \quad$ ANTI-REFLECTION AND LIGHT TRAPPING}

9177 OK Optimization of hybrid antireflection structure integrating surface texturing and multi-layer interference coating [9177-20]

$91770 \mathrm{M} \quad$ Light trapping in thin-film solar cells: the role of guided modes [9177-22]

9177 ON Light trapping in photonic crystals [9177-23]

POSTER SESSION

9177 OR Bilayer structures optimization as antireflective coating for silicon solar cells [9177-24] 


\section{Authors}

Numbers in the index correspond to the last two digits of the six-digit citation identifier (CID) article numbering system used in Proceedings of SPIE. The first four digits reflect the volume number. Base 36 numbering is employed for the last two digits and indicates the order of articles within the volume. Numbers start with 00, 01, 02, 03, 04, 05, 06, 07, 08, 09, OA, OB...0Z, followed by 10-1Z, 20-2Z, etc.

Adams, Jens, 03

Alford, N. MCN., OC

Alsmeier, J.-H., OE

Balakrishnan, Kaushik, Ol, OJ

Bär, M., OE

Bekele, Robel Y., 08

Benammar, Mohieddine A., Ol, OJ

Blum, M., OE

Brabec, Christoph J., 03

Buerhop, Claudia, 03

Chung, Simon, ix

Conibeer, Gavin, ix

Corso, A. J., OR

Cui, Yi, ON

Dai, $\mathrm{Xi}$, ix

Donchev, E., OC

Duggal, Anil R., 02

Fabritius, Tapio, 05

Falco, Charlies M., Ol, OJ

Fan, Shanhui, ON

Fan, Xiaofeng, OF

Fecher, Frank W., 03

Feng, Yu, ix

Frantz, Jesse A., 08

Gadalla, Mohammad, 04

Gammon, P. M., OC

Gorgoi, M., OE

Gupta, Neeti, ix

Heske, C., OE

Hirose, Fumihiko, OK

Hoga, Felix, 03

Holländer, B., OE

Huang, Shujuan, ix

Huber, William H., 02

Kanomata, Kensaku, OK

Konagai, Makoto, OG

Kubota, Shigeru, OK

Kurtz, Sarah, xxi

Lambertz, A., OE

Leppänen, Kimmo, 05

Liao, Yuanxun, ix

Lin, Shu, ix

Liu, Victor, ON

Mankowski, Trent, Ol, OJ

Mansuripur, Masud, Ol, OJ

Meng, Lei, OG

Miyajima, Shinsuke, OG

Myers, Jason D., 08

Nguyen, Vinh Q., 08

\author{
Ong, Khuong P., OF \\ Pang, J. S., OC \\ Patterson, Robert, ix \\ Pedersen, K., OM \\ Pedersen, T. G., OM \\ Pelizzo, M. G., OR \\ Petrov, P. K., OC \\ Raman, Aaswath, ON \\ Saarela, Juha, 05 \\ Sanghera, Jas S., 08 \\ Shikoh, Ali Sehpar, OI, OJ \\ Shrestha, Santosh, ix \\ Singh, David J., OF \\ Smyth, Suntrana, ix \\ Søndergaard, T., OM \\ Starr, D. E., OE \\ Suzuki, Takahiko, OK \\ Tayebjee, Murad, ix \\ Touati, Farid, Ol, OJ \\ Tsao, Y.-C., OM \\ Vetter, Andreas, 03 \\ Wang, Ken X., ON \\ Wang, Pei, ix \\ Weinhardt, L., OE \\ Wilks, R. G., OE \\ Wohlegemuth, John, xxi \\ Xia, Hongze, ix \\ $X \cup$, Qiang, OF \\ Yang, W., OE \\ Yu, Zongfu, ON \\ Zafar, Sayem, 04 \\ Zhang, Pengfei, ix \\ Zhang, Zhilong, ix \\ Zhu, Zhaozhao, Ol, OJ \\ Zuccon, S., OR \\ Zuppella, P., OR
}


Proc. of SPIE Vol. $9177917701-6$

Downloaded From: https://www.spiedigitallibrary.org/conference-proceedings-of-spie on 26 Apr 2023 Terms of Use: https://www.spiedigitallibrary.org/terms-of-use 


\section{Conference Committee}

Symposium Chair

Oleg V. Sulima, GE Global Research (United States)

Conference Chairs

Louay A. Eldada, Quanergy Systems, Inc. (United States)

Michael J. Heben, The University of Toledo (United States)

Conference Program Committee

Bulent Basol, EncoreSolar, Inc. (United States)

Howard M. Branz, National Renewable Energy Laboratory

(United States)

Paola Delli Veneri, ENEA (Italy)

David S. Ginley, National Renewable Energy Laboratory

(United States)

Ivan Gordon, IMEC (Belgium)

William N. Shafarman, University of Delaware (United States)

Ayodhya N. Tiwari, EMPA (Switzerland) 
Proc. of SPIE Vol. $9177917701-8$

Downloaded From: https://www.spiedigitallibrary.org/conference-proceedings-of-spie on 26 Apr 2023 Terms of Use: https://www.spiedigitallibrary.org/terms-of-use 